\title{
The Development of the Perithecium of Polystigma rubrum, DC.
}

\author{
BY \\ V. H. BLACKMAN, SC.D., F.L.S., \\ Professor of Plant Physiology and Pathology, Imperial College of Science and Technology,
}

AND

E. J. WELSFORD, F.L.S.,

Research Assistant, University of Leeds.

\section{With Plates LXX and LXXI.}

$\mathrm{O}^{\mathrm{u}}$

UR knowledge of the details of ascocarp development in the Pyrenomycetes, when compared with that of other groups of the Ascomycetes, is extremely scanty. Only a few forms have been investigated in full cytological detail, such as Aspergillus (7), Gnomonia (6), and the forms examined by Dangeard (3). An examination of Polystigma seemed then particularly desirable not only on this ground, but also from the fact that the earlier investigations of Fisch (5) in I 882 and Frank (6) in I 883 suggested that this form was of particular interest. Their observations indicated the existence of well-marked, coiled, multicellular ascogonia with trichogynes, and also of spermatia of peculiar form. Furthermore, Frank believed that he had obtained evidence of a fusion between spermatium and trichogyne indicating the occurrence of a normal sexual process. It seemed then possible that a knowledge of the cytology of this form might throw considerable light on the general question of the sexuality of the Ascomycetes and of the Lichens in particular, for the problem which apparently faces us in the Lichens, that of the fertilization by a spermatium of a multicelluiar ascogonium, has in no case been completely solved.

With these hopes, which were, however, doomed to disappointment, some tentative observations were made as far back as I905, but material in any quantity was not available till I908. Difficulties in obtaining complete stages and in elucidating the behaviour of the complicated ascogonia, together with a change of posts, have delayed the completion of the work.

[Annals of Botany, Vo1. XXVI. No, CIII. July, I912.] 
Polystigma rubrum is a fungus parasitic on Prunus spinosa and $P$. insititia, and on the cultivated plum. Its attack is confined to the leaves, on which it produces orange-yellow sclerotial patches. These patches are each the result of a separate infection and they only spread to a limited extent; with the fall of the leaf in autumn the host plant is freed from the disease. The life-history is almost identical with that of the leaf-scorch fungus (Gnomonia erythrostoma) of the cherry, but while the affected leaves of the cherry remain on the tree during the winter, the leaves attacked by P. morum fall at the usual time. This difference is no doubt related to the fact that in Polystigma there is a sclerotium, in which the perithecia develop as the leaves lie upon the ground, while in Gnomonia this structure is absent, so that if the leaves fell and rotted on the ground there would remain no basis for perithecial development.

In this country P. rubrum does not seem at all abundant. Though it is found in small quantities in various places the only locality known to us in which it occurs in any abundance is at Palling-on-Sea, Norfolk; our attention was first drawn to the fungus in this locality by Mr. George Massee.

Mycelium. The stages of actual infection of the leaf by a germ-tube from the secondary spore, which develops from the germinated ascospore, have been sufficiently investigated by Fisch (5) and Frank (6), and were not studied. The mycelium in its early stages shows thin-walled hyphae with cells containing a small number of nuclei, usually one to three. The hyphae push their way between the host cells (Pl. LXX, Fig. I) gradually, forcing them apart and bringing about their disorganization. In a mature sclerotial patch the host tissue is reduced to a few isolated cells with tanninlike contents which stain deeply; the rest of the cells having been completely absorbed (Fig. 2).

The walls of the hyphae are at first thin (Fig. I), but early in development the thin walls are modified into thick, gelatinous membranes which encroach on the cell cavity of the hyphae; these membranes usually show fine pits (Fig. 3). The gelatinous wall is no doubt of the nature of reserve material, for it appears to be in part absorbed during the later development of the perithecium after the fall of the leaf. No storage of reserve material in the form of special cell contents was to be observed.

In many well-developed sclerotial patches the hyphae form a continuous mass between the upper and the lower epidermis, the only remains of the mesophyll being the few scattered cells already mentioned. The hyphae generally contain in the fresh state an orange pigment which gives the bright colour to the sclerotial patches; it is easily soluble in alcohol. It is to be noted that in the early stages of mycelial development the hyphae congregate, especially in the intercellular spaces beneath the stomata, and often push thcir way through the stomatal pore (Figs. 4 and 5). 
Spermogonia. These arise from a group of interwoven unthickened hyphae found usually beneath a stoma. From this mass there develops the flask-shaped spermogonium (Fig. 6), which is often large enough to extend across the leaf from one epidermis to the other. The periphery of the spermogonium is formed of densely interwoven hyphae and is lined internally by the spermatia-bearing hyphae. The spermatia are borne terminally on these hyphae, which, like the spermatia, are uninucleate; but while the nuclei of the special hyphae are only slightly elongated, those of the spermatia become very long and narrow (Fig. $8 c$ ). The spermatial nucleus appears at maturity as a narrow band, staining nearly homogeneously and occupying the lower half or two-thirds of the cell (Figs. $8 a$ and $8 b$ ). The spermatia narrow at their free ends and show the peculiar curvature which has been described by earlier workers (Figs. 7 and 8). The nucleus appears in many cases to undergo early disorganization, for it may show a nodulose appearance (Fig. $8 a$ ) while the spermatia are still enclosed within the spermogonium. The spermatia are carried out of the spermogonium by a mucilaginous material which oozes from the mouth of that organ, and thus the spermatia become distributed over the surface of the leaf.

No relation of any kind was observed between the spermatia and the female reproductive organs, and attempts to bring about the germination of the spermatia ended, like those of Fisch, in failure. The spermatia must, then, be considered functionless structures, like the similarly named structures in the Uredineae.

Ascogonia. ${ }^{1}$ These structures develop from the rapidly growing ends of ordinary hyphae ; they were multinucleate in the earliest stages observed (Fig. 9). This hypha soon becomes curved and septate (Fig. IO), and gradually assumes the more or less closely coiled appearance of the mature ascogonium (Figs. II, I2, and I3). Surrounding each ascogonium is a mass of small-celled hyphae, which are uninucleate, and with walls slightly thickened. There is a great variety in the length of the ascogonia and their degree of 'coiling' (Figs. I2 and I3). One end of the ascogonium, the base, usually can be traced into a vegetative hypha, while the other ends freely in the mycelial mass (Figs. I2 and I3). A simple slightly coiled ascogonium is shown highly magnified in Fig. I2, and a more complicated one is drawn on a smaller scale in Fig. ${ }^{3} 3$.

The ascogonia are usually found in the neighbourhood of a stomata (Pl. LXX, Fig. II, and Pl. LXXI, Fig. I4), and the stoma shows the

1 Owing to the abortive nature of these coiled structures designated ascogonia by Fisch, it is impossible to say whether, primitively, they were wholly ascogonial in nature, or whether they represent archicarps of which only a portion was fertile, i. e. gave origin to the ascogenous hyphae. Under these circumstances the older name, ascogonium, may be retained, although by analogy with other cases (e. g. Lichens) we should expect the terminal portions of the coil to be sterile in nature, when the term archicarp would more fittingly describe them as a whole. 
projecting hyphae already described, but in no case could the ascogonial hypha be followed through the stoma in the form of a specially differentiated trichogyne, as described by Fisch and Frank. As already stated, the apex of the ascogonium usually ends blindly in the tissues (Pl. LXX, Figs. I 2 and I3) some distance from the stoma. In fact, of all the hundreds of ascogonia examined, in only three or four cases could the ascogonium be traced upwards towards the stoma, and even then it did not project as a differentiated trichogyne. In one of these cases the ascogonium lost itself in an ordinary hypha a little below the stoma (Fig. I1). In another case (Pl. LXXI, Fig. I4) the ascogonium was clearly abnormal, for it was much branched towards the epidermis, and gave origin to several slightly differentiated hyphae which could be traced upwards towards the hyphae projecting from the stoma. The projecting hyphae were unusually long, but were of ordinary vegetative nature and not comparable with the trichogynes described by Fisch. Only in one case was a broad hypha of a trichogynelike nature seen projecting from the stoma, and then there was no evidence of its connexion with an ascogonium. In all other cases the projecting hyphae (P1. LXX, Fig. 5) were clearly of vegetative nature, and in no case was a spermatium found attached to any of them.

The number and size of the cells which make up the ascogonium is very variable, but the majority of the cells are multinucleate, a few uninucleate cells being occasionally found. The basal cell, which connects the ascogonium with an ordinary vegetative hypha, is commonly larger than the others, and contains a large number of small nuclei (Pl. LXXI, Fig. I 5); the majority of the other cells contain about four nuclei. The nuclei usually show a chromatin network and a well-marked nucleolus, but the nuclear membrane is not generally to be distinguished. In a few of the cells of each ascogonium there is generally to be found-either alone or with other ordinary nucleia nucleus without a distinct chromatin network, but with a huge nucleolus (P1. LXX, Fig. 12, and P1. LXXI, Fig. 16 b). The origin of these special nuclei could not be traced. No convincing evidence of fusion of ascogonial nuclei could be obtained, though the common close association of the nuclei in pairs and the difference in the size of the nuclei of a single cell (Fig. 16) suggest that such fusions may still take place in spite of the abortive nature of the ascogonia.

In some cases two ascogonia may develop together, but this occurrence was not nearly so common as Fisch's description would lead one to expect.

The outgrowths of the large cells of the ascogonium figured by Fisch and described as ascogenous cells were not observed. Our observations show that the cells of the ascogonia do not become emptied of their contents, as in the functional ascogonia of Ascobolus, Humaria, \&c., but retain their contents during the process of disorganization, and so appear as darkly staining masses; this is well seen in Figs. 17 and 18 and particularly clearly in Fig. 19. 
Perithecium. This structure, though not in structural connexion with the ascogonium, arises in its neighbourhood, one perithecium being usually found in association with each ascogonium. The perithecium is first to be distinguished as a group of special hyphae which arise from the small-celled hyphae surrounding the ascogonium. These special hyphae are characterized by their long finger-like shape ; together they soon take the form of a conical mass with its apex pointed towards the lower epidermis (Figs. 77 and 18 ). Their cells may have the nuclei arranged in pairs (Fig. I8). This conical mass increases in size and develops into the flask-shaped perithecium (Fig. 24). During the early stages of development the disorganizing cells of the ascogonium can be clearly seen at its periphery (Figs. $\mathrm{J} 7,18$, and I9).

At a stage a little later than that shown in Fig. I8, ascogenous hyphae become differentiated towards the base of the young perithecium. They have no connexion with the ascogonia, but arise by differentiation from the perithecial hyphae, which are of vegetative origin as described above. The ascogenous hyphae are at first not very sharply marked, but later they are easily distinguished by their larger size, denser contents, and larger nuclei (Fig. I9). If a section be taken through the base of the perithecium at a time when the ascogenous hyphae are differentiating there may be seen (Figs. 20 and 2I), besides the nuclei in pairs mentioned earlier, larger nuclei. Nuclei in close contact are also seen, and in one case what appeared to be a stage of nuclear fusion (marked thus * in Fig. 20). There are thus indications that at this stage a nuclear fusion occurs which replaces a normal sexual fusion now lost.

The details of the formation of the asci and the ascospores were not followed, since for such work this form is not a favourable object, but a few stages were observed showing that the ascus is formed in the normal way with fusion of nuclei in the penultimate cell of an ascogenous hypha (Figs. 22 and 23).

\section{Conclusion.}

Polystigma mbrum possesses well-marked, coiled, multicellular ascogonia. The ascogonia disorganize without producing ascogenous hyphae. The spermatia also are functionless, and appear in some cases to show signs of nuclear disorganization while still within the spermogonia. The ascogenous hyphae arise near the ascogonia by differentiation from vegetative hyphae. There is a nuclear fusion in the ascus, and some evidence for an earlier nuclear fusion in the ascogenous hyphae at the time of their differentiation. Vegetative hyphae push through the stomata, but there are no trichogynes.

The divergence from the results obtained by Frank and Fisch are no doubt to be explained by the deficiencies of the primitive technique employed by earlier investigators. 
P. mbrum is to be added to the already long list of Ascomycetes in which the normal sexual process is absent. It is, however, to be distinguished from the majority of such forms by the fact that well-marked male and female reproductive organs are produced, but both are abortive. It resembles Gnomonia erythrostoma in this respect, but the ascogonia are much more clearly marked than in that form. It is probable that Xylaria is similar to Polystigma, for in that form according to Fisch the ascogonia degenerate later. In Poronia, Miss Dawson (4) finds at the base of the young perithecium ' a group of stouter deeply-stained hyphae, presumably the remains of the coil, and now representing the young ascogenous hyphae'. It is clear from this quotation that a reinvestigation of Poronia might show that the ascogenous hyphae really arise independently of the ascogonia, as in Polystigma. In Claviceps, which requires, however, further investigation, there are no ascogonia, according to Fisch (5).

The evidence to be drawn from a study of Polystigma, though not very strong, gives no support to the contention of Claussen (2) that there is only one nuclear fusion in the Ascomycetes, that in the ascus.

The expenses of this investigation were mainly defrayed by grants from the Government Grant Committee of the Royal Society.

\section{List of PAPERS.}

1. Brooks, F. T.: The Development of Gnomonia erythrostoma, Pers. Annals of Botany, vol. xxiv, I9ro, p. $5^{8} 5$.

2. Claussen, P.: Zur Entwicklungsgeschichte der Ascomyceten, Pyronema confluens. Zeitsch. f. Botanik, 4. Jahrg., I9I 2, P. I.

3. Dangeard, P.: Sur le développement du périthèce chez les Ascomycètes. Le Botaniste, vol. $x$, I 907 , p. I.

4. Dawson, M.: On the Biology of Poronia punciata. Annals of Botany, vol. xiv, 1900, p. 245.

5. Fisch, C.: Beiträge zur Entwickelungsgeschichte einiger Ascomyceten. Bot. Zeit., Jahrg. 40, 1882, p. 850.

6. FRANK, B. : Ueber einige neue oder weniger bekannte Pflanzenkrankheiten. Ber. d. deutsch. bot. Ges., Bd. i, $188_{3}$, p. $5^{8}$.

7. Fraser, H. C. J., and Chambers, H. S.: The Morphology of Aspergillus herbariorum. Ann. Mycologici, vol. v, I907, p. 4I9. 


\section{EXPLANATION OF PLATES LXX AND LXXI.}

Illustrating the paper by Professor V. H. Blackman and Miss Welsford on Polystigma rubrum.

\section{PLATE LXX.}

The preparations are mostly from material fixed in Flemming's strong fluid (half strength) or acetic alcohol and stained with iron-alum-haematoxylin.

Fig. I. Leaf-cells of host with hyphae of fungus pushing between them; the cell on the right is dead and has darkly staining contents. $\times \mathrm{I}, 200$.

Fig. 2. Later stage in the formation of a sclerotial patch. The host cells, with deeply staining tannin-like contents, are dead, and have been pushed apart by the action of the fungus. $\times 1,200$.

Fig. 3. Older hyphae of sclerotial patch with thick walls, showing fine pits. $\times 1,800$.

Fig. 4. Aggregation of hyphae beneath the stomata on the under surface of the leaf. $\times 900$.

Fig. 5. Section through leaf in the plane of the guard cells, showing one guard cell and hyphae projecting through the stomatal pore. $\times 800$.

Fig. 6. Section through leaf, showing a spermogonium. $\times 300$.

Figs. $7 a$ and 7 b. Two spermatia unstained and mounted in a watery medium. $\times 1,800$.

Figs. $8 a$ and $8 b$. Stained spermatia, showing the elongated nucleus. $\times \mathrm{I}, 800$.

Fig. 8 c. Spermatial hypha with base of spermatium above, with elongated nucleus. $\times \mathrm{J}, 800$.

Fig. 9. Very early stage in the development of an ascogonium; the terminal portion of a vegetative hypha shows four nuclei and is the future ascogonium. $\times \mathrm{I}, 800$.

Fig. Io. Later stage in the development of the ascogonium, which has now become coiled, and shows at least one septum. $\times 1,800$.

Fig. II. Section showing coiled ascogonium in the neighbourhood of a stoma through which ordinary vegetative hyphae are seen projecting. The four irregular masses are disorganized mesophyll cells. $\times 900$.

Fig. I 2. Mature ascogonium of simple form, showing details of cells and nuclei. The basal end can be traced into a vegetative hypha, while the other ends freely. Some of the nuclei show a large nucleolus and little chromatin; others show a small nucleolus and ample chromatin. $\times 1,300$.

Fig. I3. A more complicated ascogonium than that of Fig. I2. $\quad \times 800$.

\section{PLATE LXXI.}

Fig. I4. Abnormally branched ascogonium. One or more of the branches apparently projects from the stoma as an ordinary vegetative hypha. $\times 800$.

Fig. I 5. Basal cell of ascogonium, showing a large number of small nuclei. $\times 1,200$.

Figs. $16 a$ and $16 b$. Several cells of an ascogonium, showing the distinction of size and appearance of the nuclei. $\times$ I, 200 .

Fig. I7. Early stage of perithecium as a cone-shaped mass of vegetative hyphae. The disorganizing ascogonial cells are seen at the periphery and at the centre. $\times 800$.

Fig. 18. Young perithecium a little older than that of Fig. I7. The ascogenous hyphae are not yet clearly to be distinguished, but many of the nuclei of the perithecial cells are clearly arranged in pairs. The darkly stained masses at the periphery are the disorganizing cells of the ascogonium. $\times 800$.

Fig. I9. Later stage of young perithecium with ascogenous hyphae well differentiated by their larger size, denser contents, and larger nuclei. Remains of ascogonium still visible. $\times$ r, 200.

Fig. 20. Section through base of young perithecium at a time when the ascogenous hyphae are becoming differentiated. There are indications of nuclear fusions, especially at the point marked with a star, and also in the paired condition of many nuclei and the larger size of others. $\quad \times \quad$,, 800 .

Fig. 2I. Cells at base of young perithecium with two nuclei in contact, indicating a stage before fusion. $\times I, 800$.

Fig. 22. Young ascus still binucleate, occupying the typical position at end of an ascogenons hypha. $\times 2,700$.

Fig. 23. An ascus in a stage somewhat later than that of Fig. 22. The two nuclei have fused, but the nucleoli remain distinct. $\times \mathrm{I}, 800$.

Fig. 24. Section through mature perithecium. Many of the younger asci are disorganized. $\times 300$. 
Annals of Botany



1.

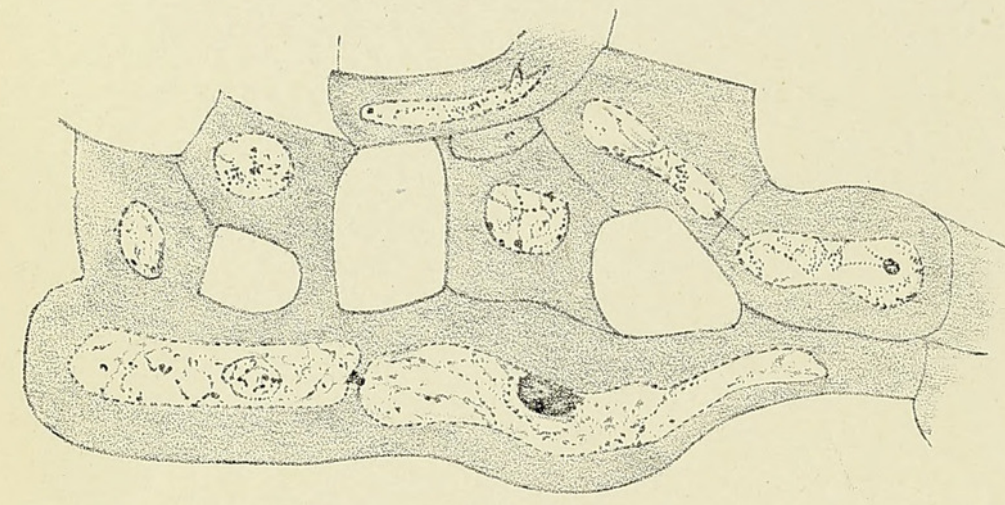

3.

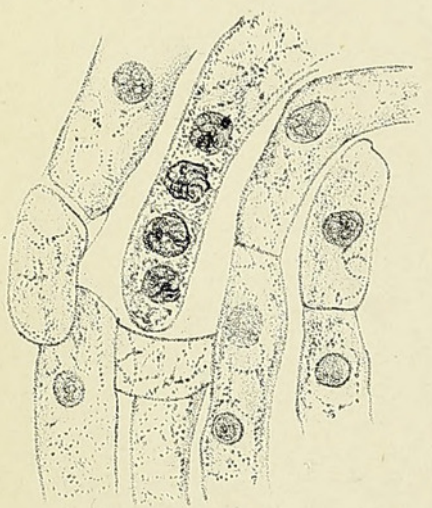

9.
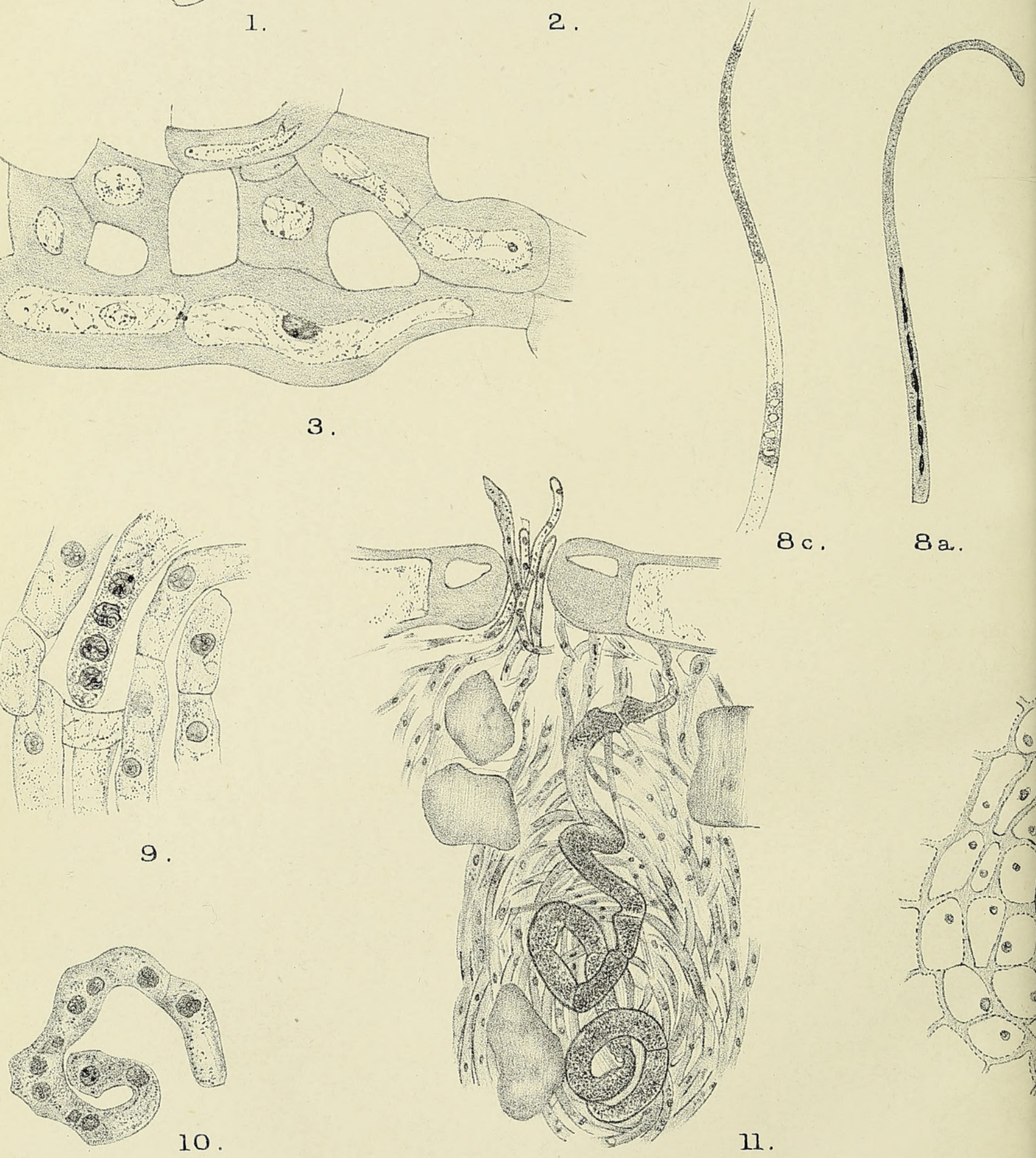

$8 \mathrm{c}$.

8 a.

E.J.W. del. 


\section{Annals of Botany}



1.

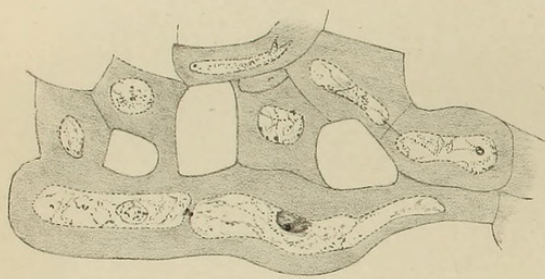

3.

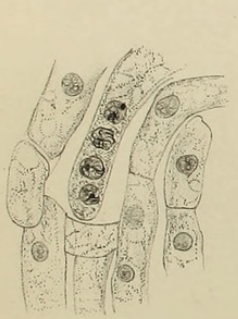

9.


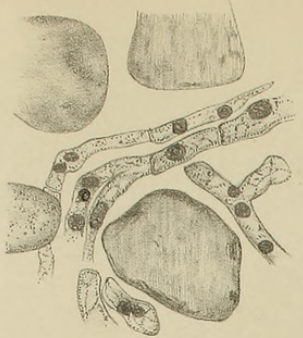

2 .

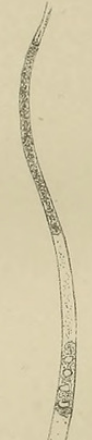

$8 \mathrm{c}$.
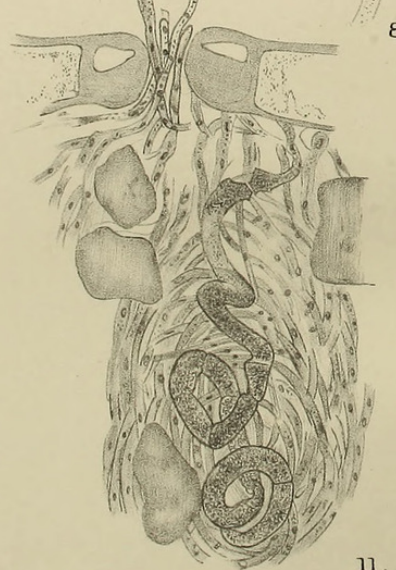

11.
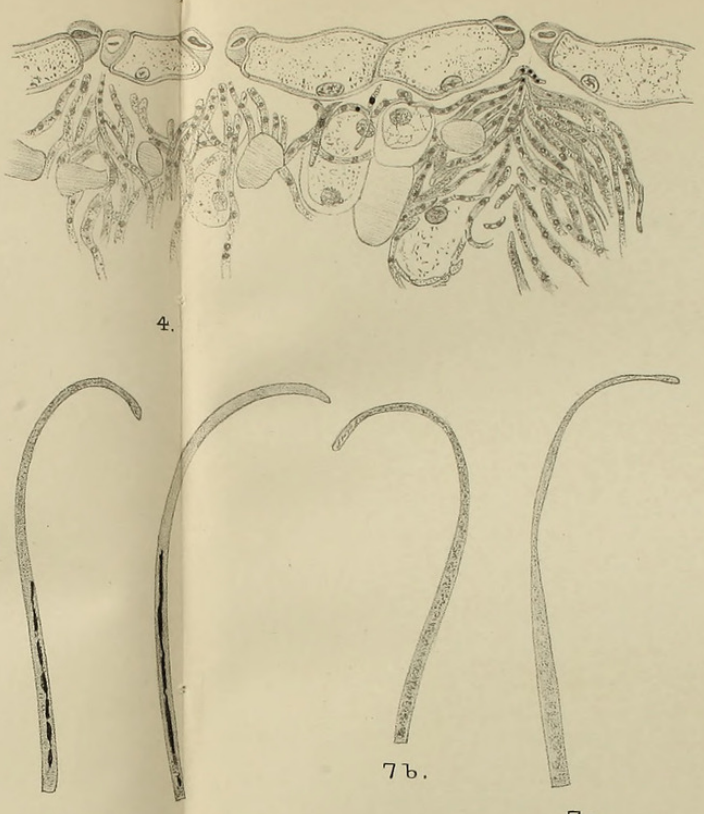

8 a.

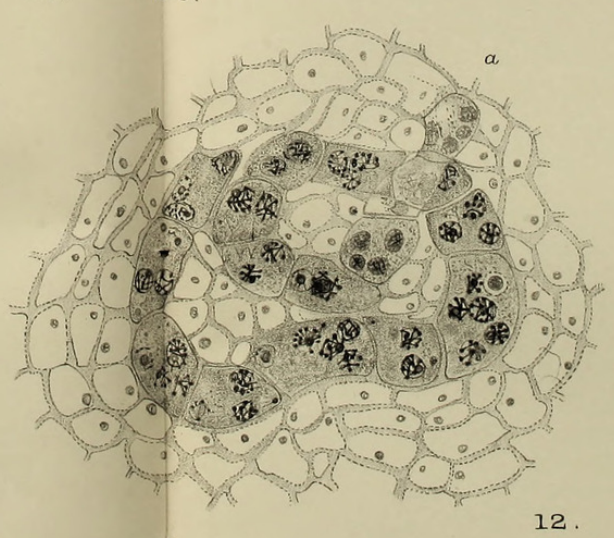

Vol.XXVI, PZ.LXX.
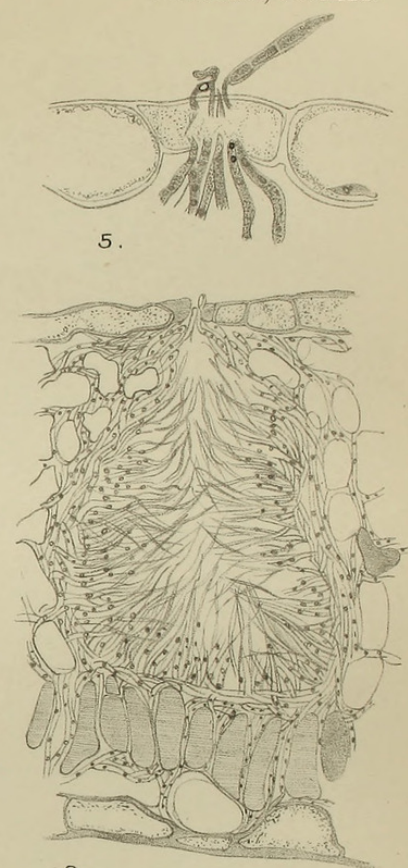

6

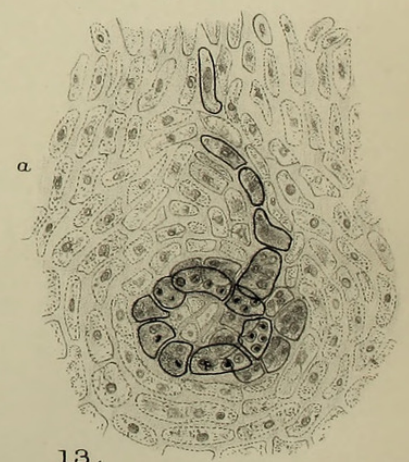

BLACKMAN \& WELSFORD-POLYSTIGMA. 
Arrials of Botany,

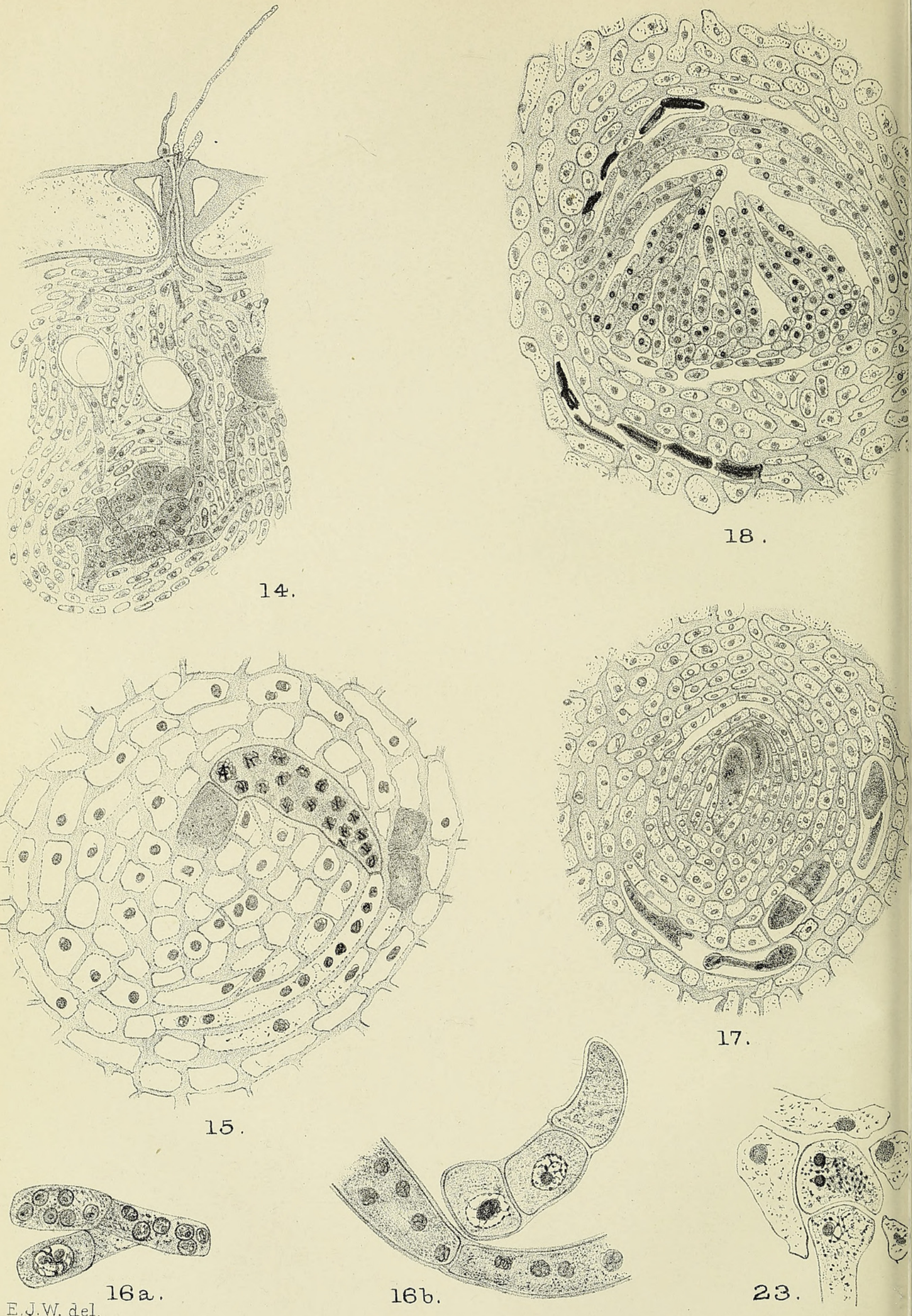

BLACKMAN \& WELSFORD - POLYSTIGMA , 
Vol. XXVI, Pl.LXXI.



19.

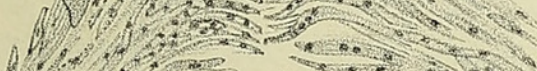

160 of en

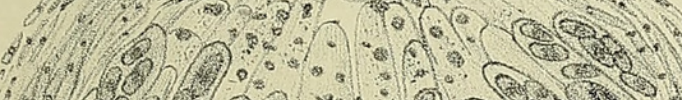

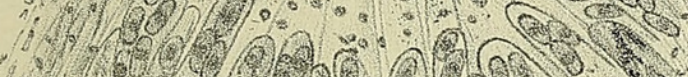

1.

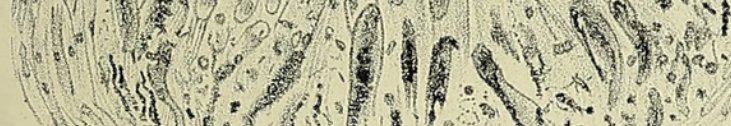

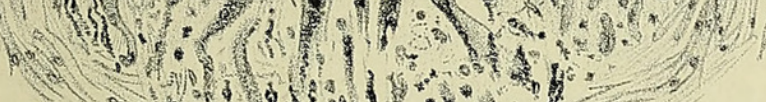

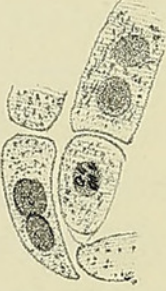

21.

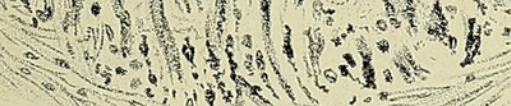

24.

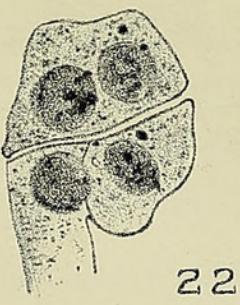

20 .

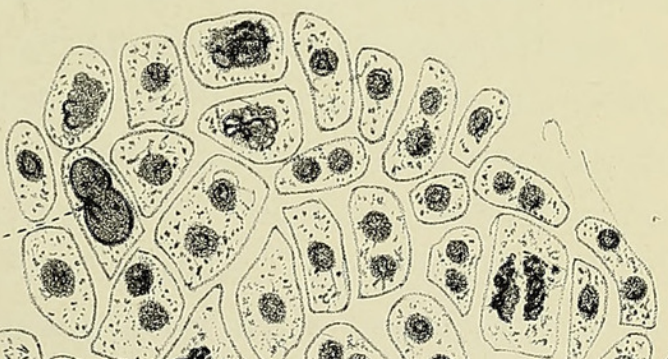

1. $60 \sqrt{6} 6$

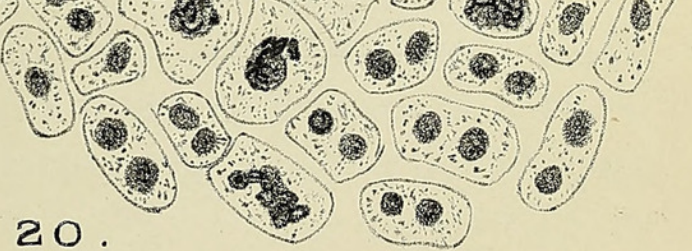

Huth lith et imp. 
Arrials of Botany,
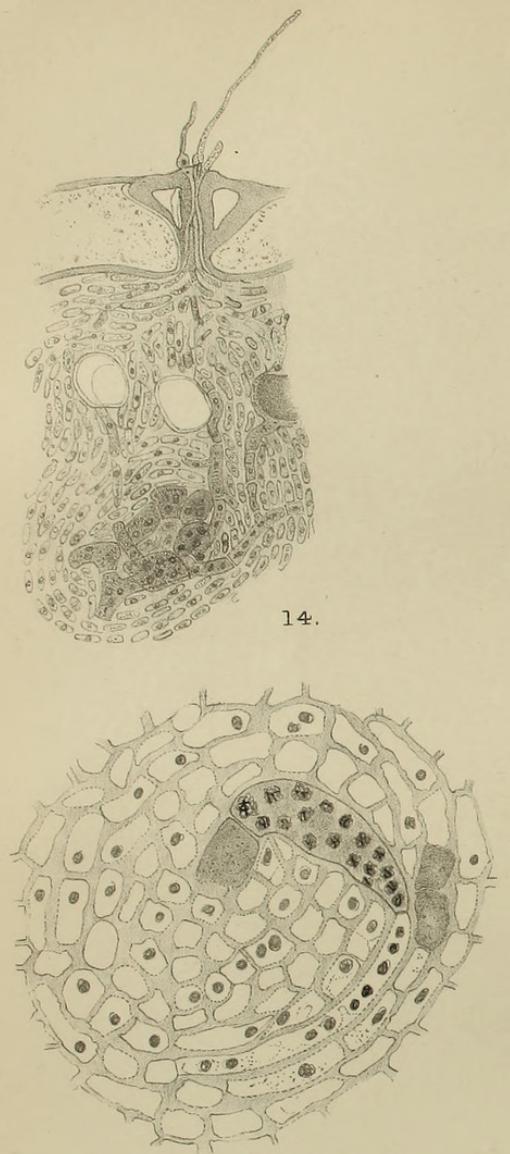

15



E.J.W. 16a.

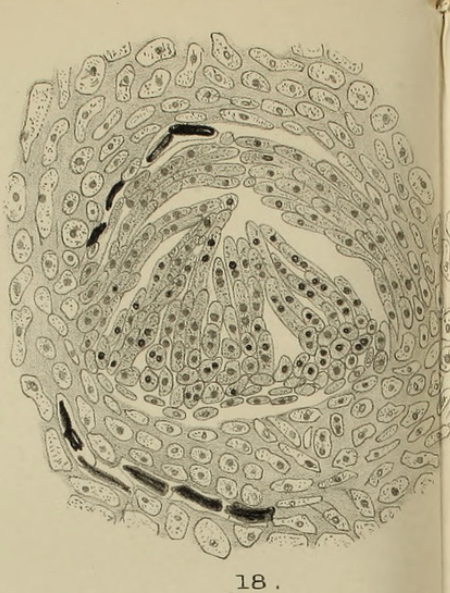

18.

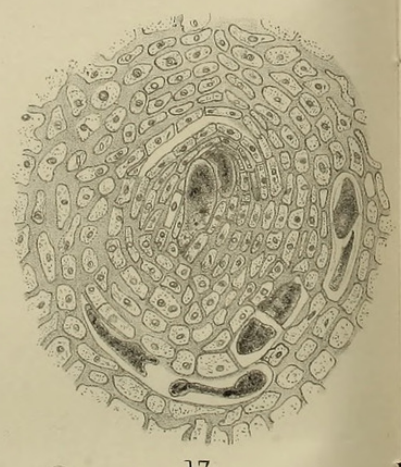

17.

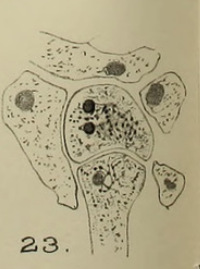





19.

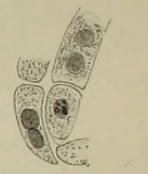

21.
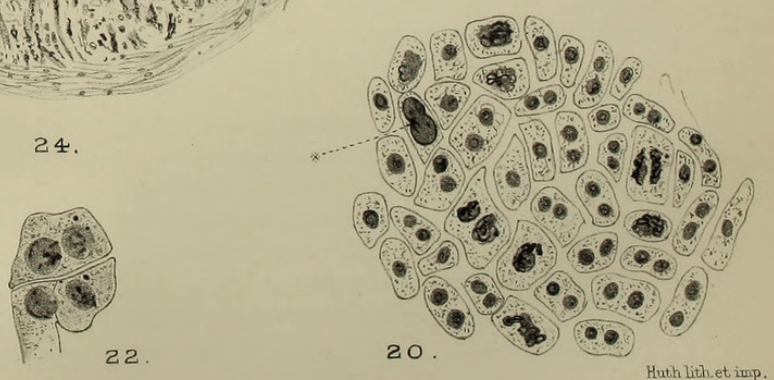


\section{$2 \mathrm{BHL}$ Biodiversity Heritage Library}

Blackman, Vernon H. and Welsford, E. J. 1912. "The development of the perithecium of Polystigma rubrum, DC." Annals of botany 26, 761-767. https://doi.org/10.1093/oxfordjournals.aob.a089414.

View This Item Online: https://www.biodiversitylibrary.org/item/236930

DOI: https://doi.org/10.1093/oxfordjournals.aob.a089414

Permalink: https://www.biodiversitylibrary.org/partpdf/319927

\section{Holding Institution}

Smithsonian Libraries

\section{Sponsored by}

Biodiversity Heritage Library

\section{Copyright \& Reuse}

Copyright Status: Not in copyright. The BHL knows of no copyright restrictions on this item.

This document was created from content at the Biodiversity Heritage Library, the world's largest open access digital library for biodiversity literature and archives. Visit BHL at https://www.biodiversitylibrary.org. 